\title{
Online Learning Management in The Covid-19 Pandemic ERA
}

\author{
Herry Sanoto $^{1}$ \\ 1) FKIP, UKSW, Salatiga, Indonesia \\ E-mail: Herry.sanoto@uksw.edu
}

\begin{abstract}
Learning in the era of the Covid-19 pandemic has undergone a fundamental change from a face-to-face learning process to online-based learning to minimize the transmission of the Covid-19 virus. Online learning is basically a learning model with internet technology media, so that the learning process can be carried out even though it is in different places. The research method in this research is qualitative research by describing the online learning management process that is carried out at SMP LAB UKSW. The instruments in this research include observation sheets, student opinion questionnaires, and interview guides. The results showed that the online learning process applies management principles which include planning, organizing, implementing and controlling. The results of student and teacher opinions show that online learning has a positive perception of $83 \%$. The results of the interview showed that the students felt that they were well facilitated by the online learning process that was conducted at SMP LAB UKSW.
\end{abstract}

Keywords: Online Learning, Learning Management, Pandemic, Covid-19

\section{INTRODUCTION}

Education is a bridge in achieving the goals of a nation to develop and become a great nation. The Indonesian nation sees education as a tool to achieve the ideals of the nation that has been formulated by the founding father nation's. Through the National Education System Law Number 20 of 2003 Education has priority and receives a minimum budget slot of $20 \%$ of the Indonesian State Budget. The era of the Covid-19 pandemic is a moment that is influential in all aspects of human life, starting from the aspects of health, economics, even in aspects of education (Lopes \& McKay, 2020). Many countries apply very strict health protocols, even locating areas to reduce the spread of the covid-19 virus. Even though Indonesia does not implement a national lockdown, the government has placed restrictions on community activities. As a result, many community activities are limited or even eliminated. This is no exception in the learning process at school, all schools dismiss their students and teachers and eliminate face-to-face learning in place of online learning.

Online learning is the most realistic solution in the midst of limiting community activities. Online learning is a learning process that uses internet technology media, so that the learning process can be carried out even though it is in a different place (Kintu, Zhu, \& Kagambe, 2017; Wei \& Chou, 2020). In addition, online learning is a learning process in which students realize that learning remotely from learning sources, namely teachers and without direct interaction with teachers and friends, such as in a face-to-face learning environment (Hrastinski, 2019). The online-based learning process facilitates students to continue learning in conditions that do not allow face-to-face learning. Online learning not only encourages the use of technology for the teaching and learning process but also encourages the development of pedagogical subjects that focus on learning and the use of digital resources and communication tools. This type of learning successfully supports learning and facilitates pedagogical decision making (Hergüner, Buğra SON, Hergüner Son, \& Dönmez, 2020; Hsiao, E-Ling, Peter, Shih, \& Ya-Ting, 2015).

Online learning is a part of e-learning that has long been applied in the learning process, especially at the university level. E-learning based learning has the benefit of opening opportunities to implement innovative learning environments, where students are required to be active, independent, reflective, and collaborative. Compared to classical learning (namely face-to-face learning, seminars, and lectures) e-learning has clear advantages because it provides space and time flexibility during the learning process (Widyanti \& Park, 2020). One of the successes of elearning is the need for students' readiness to implement Elearning such as good learning independence, being active in finding learning resources and teachers being able to become facilitators in the learning process (Müller, Goh, Lim, \& Gao, 2021). Student readiness / student readiness in the e-learning learning process is a problem for junior high school aged students, because the learning process when depending on the teacher as the main learning source (Nuryanti, Zubaidah, 
\& Diantoro, 2018). Another problem in the process of implementing online learning in the Covid-19 pandemic era is that not all students can have adequate internet access so that the online learning process by means of video conferencing cannot be carried out properly, so it cannot reach all students.

In order to overcome the problem of limited access, an online learning process management is compiled that can regulate the process and course of learning to be effective and can achieve learning objectives. Educational management helps in the process of realizing effective learning (Chychuk, 2016). Management is the achievement of organizational goals effectively and efficiently through planning, organizing, directing, and controlling organizational resources. This definition holds two important ideas: (1) four functions of planning, organizing, leading, and controlling, and (2) achieving organizational goals effectively and efficiently (Richard L. Daft; Patricia G. Lane, 2010). According to George R. Terry, the management function consists of Planning, Organizing, Actuating and Controlling (Nuridin, 2015). Planning is the process of formulating and planning the activities needed to achieve the desired individual / group. Organizing is a step to determine, classify and prepare the activities needed to achieve goals. Actuating is the implementation of achieving proper planning and organizing efforts to arouse and encourage all members. Controlling is the process of determining what must be achieved, if it is not according to plan, it is necessary to improve.

This research discusses the online learning process management process that is carried out at the SWCU LAB Middle School in carrying out the learning process even though it is in limited conditions because there are restrictions on community activities so face-to-face learning is not possible.

\section{METHOD}

This research uses qualitative research methods, qualitative research methods are research methods used to examine the condition of natural objects, with the researcher as the key instrument, the data collection technique is done by triangulation (a combination of interviews, observation, documentation) (Sukestiyarno, 2020). This research discusses online learning management that is carried out in junior high schools so that learning that has been implemented becomes effective and easy learning to be carried out by teachers and students.

The research subjects in this study were the SWCU LAB Middle School teachers and students who were doing online learning. The research instruments used in this study were teacher opinion questionnaires, student opinion questionnaires, and interviews with teachers and students.

Data obtained based on the results of observations, interviews and documents obtained during the research process was carried out. The focus in this research is the online learning management process carried out by the teacher so that the learning process can run effectively even in the conditions of the Covid-19 pandemic.
In the research process, a management process was carried out, namely planning, organizing, actuating and controlling.

\section{III.RESULTS AND DISCUSSION}

Based on the results of observations and interviews that have been carried out, the online learning process has been implemented since the beginning, restrictions on community activities have been implemented. After the status of restrictions on community activities is determined, educational activities at schools are temporarily closed, and educational activities are not carried out in schools. Teachers and teaching staff at schools are on vacation and carry out picket schedules in turn at school. After running for some time, online learning was proclaimed, because it was impossible for the learning process to be closed continuously, and also the Covid-19 pandemic was not yet known when it would end. The Covid-19 pandemic is very influential and disrupts the learning process at every level of school (Korkmaz \& Toraman, 2020; Süt \& Öznaçar, 2021). So it needs preparation and planning about the learning process that is applied in the era of the Covid-19 pandemic (Hanuschek et al., 2020; Kuhfeld et al., 2020). Online learning is the most appropriate and suitable solution to overcome the limited learning process during the Covid-19 pandemic (Ali, 2020; Bestiantono et al., 2020; Dhawan, 2020)

With this combined condition, the online learning process is carried out with the preparation process of the teacher by conducting coordination meetings between teachers, school principals, and the education office so as to produce an online learning model that can be implemented during the Covid-19 pandemic

Based on the research results obtained are described as follows:

\section{A. Planning}

Planning / planning is the process of identifying the goals to be achieved and deciding the tasks and use of the resources needed to achieve them. In other words, planning determines the steps and strategies you want to implement and how to achieve them (Richard L. Daft; Patricia G. Lane, 2010).

Based on the results of the interviews, it was found that in carrying out online learning there was some coordination from various parties including teachers, schools, and related education offices. The planning step in the online learning process is carried out by holding discussions with teachers at school and discussing the online learning process that is appropriate for junior high school students. It should be noted that SMP LAB is a school located in the City of Salatiga, with the majority of students living in the area around the City of Salatiga. The settlements around the City of Salatiga are close to Mount Merbabu, so that geographically it is hilly and not all areas can be well reached by signals. In addition, there are limitations for students in accessing the internet. 
Based on this background, several online learning strategies that can be implemented are produced, namely:

1) The learning process using the WA Media (Whatsapp). Whatsapp is a communication medium that is already popular and widely used by the community. With limited time and easier use, Whatsapp has become an intermediary medium between teachers and students to provide learning materials both modules and also practice questions (Alaby, 2020). Whatsapp media was chosen because it is easy to use and familiar to parents and students in using it. So that the school does not need to carry out training which basically cannot be carried out because of restrictions on community activities. Whatsapp media is a bridge between teachers and students in the middle of the online learning process, besides that WA has the advantage of being able to send messages, documents, videos, and can also do video teleconferences if needed (Cetinkaya, 2017).

2) Using Google Classroom. Media Another supporting media chosen in the online learning process is to use Google Classroom. Through the google classroom media the teacher can send materials, assignments, and exercises to students. Google Classroom is an educational media platform designed for online learning. In addition, google classroom has several features that support online learning (Suhada et al., 2020). However, the weakness of the google classroom is that not all students can use the media, so it takes time in the process of using it so that it cannot be used immediately.

The two strategies are implemented based on needs and aspects of use that are easier to implement. The online video conference learning process is not the main strategy in the online learning process at the SWCU LAB Middle School, because of the limited internet access and students' understanding of other online-based media.

Assignments are a learning strategy used in the online learning process. Online learning demands student learning independence in understanding material, practicing and asking questions (Beach, 2017; Yuliati \& Saputra, 2020). Assignments encourage students to be independent in learning and not depend on the teacher in the learning process. The right assignment load makes students more organized and accustomed to learning and increases motivation in student learning (Sutarna, 2016).

The process of collecting student work results is planned into two steps, namely:submission of

1) Online collection Assignments. Online collection of assignments is carried out by submitting assignments through Whatsapp media and can use the google classroom application. So that the teacher can monitor the student learning process through the assignments that have been given

2) Offline collection assignment Offline collection assignment is a strategy used if it meets the provisions, namely the area in Salatiga District is included in the green zone. So that it allows students to go to school and collect assignments that have previously been given by the teacher.

\section{B. Organizing}

Organizing involves assigning tasks, grouping tasks into departments, delegating authority, and allocating resources throughout the organization (Richard L. Daft; Patricia G. Lane, 2010).

Organizing in this study is the process of organizing a predetermined plan. The organizing process includes the division of lesson hours for each subject, the process of distributing material and assigning teachers to students. In facilitating coordination between teachers and students, groups between subjects are created to make it easier for students in the teacher to communicate.

The media used first was Whatsapp media because it was easier to operate in helping the learning process online. Meanwhile, the google classroom media is used in stages, and the teacher gives prior directions to students so that it will make it easier for both teachers and students to use it. In this organizing process, the number of hours of lessons reduced is not the same as face-to-face learning so that students find it easier to learn independently at home.

At this stage the school arranges the details of the online learning schedule to be carried out, this process is expected to ensure that online learning does not give a burden to students and parents to carry out the learning process. Assignments that are carried out are also given in accordance with the learning portion of students at home by paying attention to health principles. The right number of assignments can have a positive effect, but if it is excessive, it can create a burden for students (Sholeh, 2020).

\section{Actuating}

Actuating process or implementation there are several obstacles such as not all students can understand the instructions and instructions of the teacher in providing material in the form of modules or questions. Another obstacle is that the large number of assignments that students submit to the teacher makes the recap and assessment process more complicated and increases the teacher's time to check so that data recap errors may occur. Handling that is carried out related to this problem is by scheduling students in each class to collect assignments and carry out offline discussions in class with limited time and number of students. This can be done because the status of the area in the Salatiga District area has become a green zone, so that students are allowed to come to school with a schedule with a limited number of students and still comply with the established health protocols. In addition, training on the use of google classroom is conducted regularly for students, so that they can use the application in the online learning process so that it makes it easier for teachers and students to learn.

\section{Controlling \\ Controlling in this research process is the process of monitoring and evaluating programs that have been}


implemented in the online learning process. Controlling includes monitoring the online learning process and the obstacles that arise in the process. The obstacle in the online learning process at the SWCU LAB Middle School was the ineffective learning using video conferencing using the WA application, google meet, and also zoom. This occurs from not all regions having good internet network access so that not all students can follow the process so that the learning process is replaced by providing modules that are easy for students to understand and also the teacher distributes learning videos that support the student's learning process. So that the explanation related to the material is not only through modules and exercises but is also explained in a video that can be seen by students via YouTube, and is more easily accessible than conducting learning video conferences.

\section{Perceptions of Online Learning}

Teachers 'and students' perceptions of online learning were measured based on a questionnaire given to teachers and students. The results of the questionnaire showed that online learning that was designed at the SWCU LAB Middle School obtained a percentage of $83 \%$, which means that online learning gets a positive perception. This positive perception can be interpreted that online learning can help students learn even though there are several limitations they have. This is in accordance with the research of Satrianingrum \& Prasetyo, (2020) that online learning is a learning solution in the midst of the Covid-19 pandemic.

\section{Online Learning Opinion Sheet}

Researchers also conducted interviews and distributed questionnaires to teachers and students in the online learning process that had been implemented. The results of the teacher and student opinions are explained as follows.

1) Teacher. Teacher said that the online learning process needed adjustments first, both in terms of the learning process, making modules that were easy for students to understand and giving assignments that were able to train students to be able to study independently at home. Not all materials can be implemented easily with online learning, one of which is mathematics. Mathematics learning still really needs the delivery of material from the teacher and examples from the teacher. Another problem is that students are not accustomed to independent learning and are able to understand the material presented through modules or exercises

2) Students. Based on questionnaires and interviews conducted with students, it shows that online learning cannot be understood by students directly. Students have not been able to understand the explanation given by the teacher through the module and also the practice questions given. Parents have a very major role in online learning, because students ask for explanations and directions from parents in learning. Students also have limitations in operating media that help in the online learning process, for example google classroom. On average students are unable to use google classroom and the majority use WhatsApp media.

The results of field studies show that online learning is the right solution in dealing with the Covid-19 pandemic so that the learning process continues to run well, this is in accordance with the research that has been carried out by (Dhawan, 2020; Fields \& Hartnett, 2020; Giatman, Siswati, \& Basri, 2020; Hamid, Sentryo, \& Hasan, 2020). In addition, independent learning is needed in order to be able to carry out online learning well, this is in accordance with research (Atmojo, Muhtarom, \& Lukito Aji, 2020; Durnalı, 2020; Landrum, 2020; Reysen, 2017; Sharp \& Sharp, 2016; Wong et al. ., 2019)

\section{CONCLUSION AND SUGGESTIONS}

The results of the study show that in the online learning management process of the SWCU LAB Middle School, it has carried out stages including Planning, Organizing, Actuating, and Controlling.

$>$ Planning begins with designing an online learning scheme, namely using Whatsapp media and also Google Classroom.

$>$ Organizing is done by organizing tasks and scheduling well so that the online learning process runs smoothly.

$>$ Actuating is the implementation of online learning based on a pre-arranged plan.

$>$ Controlling is the stage of monitoring the course of online learning as planned and evaluating regularly, one of which is offline assignment collection.

Based on the teacher's and student's perception sheet, it shows that the online learning process gets positive perceptions and is the right solution in learning activities in the midst of the Covid-19 pandemic.

In addition to the above, online learning still has problems, namely regarding student learning independence which is still lacking and also training in the use of online learning media, because there are still many students who have not mastered applications such as google classroom.

Suggestions for research related to online learning management are to provide the best online learning design or management that teachers and students can implement in the online learning process.

\section{REFERENCES}

Alaby, M. A. (2020). Media Sosial Whatsapp Sebagai Media Pembelajaran Jarak Jauh Mata Kuliah Ilmu Sosial Budaya Dasar (ISBD). Ganaya: Jurnal Ilmu Sosial Dan Humaniora, 3(2), 273-289.

Ali, W. (2020). Online and Remote Learning in Higher Education Institutes: A Necessity in light of COVID-19 Pandemic. Higher Education Studies, 10(3), 16.

Atmojo, S. E., Muhtarom, T., \& Lukitoaji, B. D. (2020). The level of self-regulated learning and self-awareness 
in science learning in the covid-19 pandemic era.

Jurnal Pendidikan IPA Indonesia, 9(4), 512-520.

Beach, P. (2017). Self-directed online learning: A theoretical model for understanding elementary teachers' online learning experiences. Teaching and Teacher Education, 61, 60-72.

Bestiantono, D. S., Agustina, P. Z. R., \& Cheng, T.-H. (2020). How Students' Perspectives about Online Learning Amid the COVID-19 Pandemic? Studies in Learning and Teaching, 1(3), 133-139.

Cetinkaya, L. (2017). The impact of whatsapp use on success in education process. International Review of Research in Open and Distance Learning, 18(7), 59-74.

Chychuk, A. (2016). The System of Teacher Education Management in Great Britain. Comparative Professional Pedagogy, 5(4), 80-86.

Dhawan, S. (2020). Online Learning: A Panacea in the Time of COVID-19 Crisis. Journal of Educational Technology Systems, 49(1), 5-22.

Durnal1, M. (2020). The effect of self-directed learning on the relationship between self-leadership and online learning among university students in Turkey. Tuning Journal for Higher Education, 8(1), 129165.

Fields, A., \& Hartnett, M. (2020). Online teaching and learning: COVID-19 Special Issue. Journal of Open, Flexible and Distance Learning, 4(COVID19 Special Issue), 19-20.

Giatman, M., Siswati, S., \& Basri, I. Y. (2020). Online Learning Quality Control in the Pandemic Covid-19 Era in Indonesia. Journal of Nonformal Education, 6(2), 168-175.

Hamid, R., Sentryo, I., \& Hasan, S. (2020). Online learning and its problems in the Covid-19 emergency period. Jurnal Prima Edukasia, 8(1), 86-95.

Hanuschek, E. A., Woessmann, L., Hanushek, E., \& Woessmann, L. (2020). OECD iLibrary | The economic impacts of learning losses. September.

Hergüner, G., Buğra SON, S., Hergüner Son, S., \& Dönmez, A. (2020). The effect of online leearning attitudes of university Students on their Online Learning Readiness. TOJET: The Turkish Online Journal of Educational Technology, 19(4), 102-111.

Hrastinski, S. (2019). What Do We Mean by Blended Learning? TechTrends, 63(5), 564-569.

Hsiao, E-Ling, Peter, Shih, \& Ya-Ting. (2015). Establishing a Multimedia-Rich Environment to Support Experiential e-Learning in Business Education. Acta Universitatis Agriculturae et Silviculturae Mendelianae Brunensis, 53(9), 1689-1699.

Kintu, M. J., Zhu, C., \& Kagambe, E. (2017). Blended learning effectiveness: the relationship between student characteristics, design features and outcomes. International Journal of Educational Technology in Higher Education, 14(1).

Korkmaz, G., \& Toraman, Ç. (2020). Are We Ready for the Post-COVID-19 Educational Practice? An
Investigation into What Educators Think as to Online Learning. International Journal of Technology in Education and Science, 4(4), 293 309.

Kuhfeld, M., Soland, J., Tarasawa, B., Johnson, A., Ruzek, E., \& Liu, J. (2020). Projecting the Potential Impact of COVID-19 School Closures on Academic Achievement. Educational Researcher, 49(8), 549 565.

Landrum, B. (2020). Examining students' confidence to learn online, self-regulation skills and perceptions of satisfaction and usefulness of online classes. Online Learning Journal, 24(3), 128-146.

Lopes, H., \& McKay, V. (2020). Adult learning and education as a tool to contain pandemics: The COVID-19 experience. International Review of Education, 66(4), 575-602.

Müller, A. M., Goh, C., Lim, L. Z., \& Gao, X. (2021). Covid-19 emergency elearning and beyond: Experiences and perspectives of university educators. Education Sciences, 11(1), 1-15.

Nuridin. (2015). the Development Model of Students ' Guidance Management Based. International Journal of Education and Research, 3(2), 157-168.

Nuryanti, L., Zubaidah, S., \& Diantoro, M. (2018). Analisis Kemampuan Berpikir Kritis Siswa SMP. Jurnal Pendidikan: Teori, Penelitian, Dan Pengembangan, 3(2), 155-158.

Reysen, R. H. (2017). International Journal of Self-Directed Learning. March 2015.

Richard L. Daft; Patricia G. Lane. (2010). Management. In Management.

Satrianingrum, A. P., \& Prasetyo, I. (2020). Persepsi Guru Dampak Pandemi Covid-19 terhadap Pelaksanaan Pembelajaran Daring di PAUD. Jurnal Obsesi : Jurnal Pendidikan Anak Usia Dini, 5(1), 633.

Sharp, L., \& Sharp, J. (2016). Enhancing Student Success in Online Learning Experiences through the Use of Self-Regulation Strategies. Journal on Excellence in College Teaching, 27(2), 57-75.

Sholeh, M. B. (2020). Implementation of Task-based Learning in Teaching English in Indonesia: Benefits and Problems. Language Circle: Journal of Language and Literature, 15(1), 1-9.

Suhada, I., Kurniati, T., Pramadi, A., Listiawati, M., Biologi, P. P., Gunung, S., \& Bandung, D. (2020). Pembelajaran Daring Berbasis Google Classroom Mahasiswa Pendidikan Biologi Pada Masa Wabah Covid-19. Digital Library UIN Sunan Gunung Jati, 2019, 1-9.

Sukestiyarno. (2020). Metode Penelitian Pendidikan. UNNES PRESS.

Süt, H. M., \& Öznaçar, B. (2021). Effects of COVID-19 Period on Educational Systems and Institutions. International Journal of Curriculum and Instruction, 13(1), 537-551.

Sutarna, N. (2016). Penerapan Metode Penugasan Untuk Meningkatkan Kemampuan Memahami Peta Pada 
Siswa Sekolah Dasar. Jurnal Geografi Gea, 16(1), 34.

Wei, H. C., \& Chou, C. (2020). Online learning performance and satisfaction: do perceptions and readiness matter? Distance Education, 41(1), 48-69.

Widyanti, A., \& Park, J. (2020). e-Learning readiness and perceived learning workload among students in an Indonesian university Bandung Institute of Technology (ITB ), Indonesia Recommended citation: e-Learning readiness and perceived learning workload among students in an Indonesian. Knowledge Management And E -Learning, 12(1), 18-29.

Wong, J., Baars, M., Davis, D., Van Der Zee, T., Houben, G. J., \& Paas, F. (2019). Supporting Self-Regulated Learning in Online Learning Environments and MOOCs: A Systematic Review. International Journal of Human-Computer Interaction, 35(4-5), 356-373.

Yuliati, Y., \& Saputra, D. S. (2020). Membangun Kemandirian Belajar Mahasiswa Melalui Blended Learning Di Masa Pandemi Covid-19. Jurnal Elementaria Edukasia, 3(1), 142-149. 